\title{
Scientific Attitude Levels of Gifted Students (A Case from Malatya)
}

\author{
İsmail ȘAN*
}

\author{
Ali İhsan BORAN ${ }^{* *}$
}

Received: 05 July 2012

Accepted: 01 May 2013

\begin{abstract}
The purpose of this study was twofold: (1) to determine scientific attitude levels of gifted students, and (2) to investigate whether their levels of scientific attitude differ on selected demographic variables. The sample of this survey study consisted of 147 gifted 12-16-year-old students studying in Malatya Science and Arts Center. Data were collected through the "Scientific Attitude Scale" developed by Battal and Gürgan (1998). The reliability coefficient was calculated as 0.708 . Frequency and percentage tables, $t$ tests, analyses of variance and chi-square tests were employed to analyze the data. Results showed that scientific attitude levels of gifted students are high and do not differ on gender, monthly income, level of parental education, and occupational status of mothers. According to chi-square test results, some differences between observed and expected data were detected and reported in the paper. Finally, some recommendations were made to develop scientific attitudes of gifted students.
\end{abstract}

Key words: gifted student, scientific attitude, Science and Arts Center (SAC).

\section{Extended Abstract}

Purpose and Significance: Giftedness is defined as the combination of above-average ability, sense of duty and creative thinking (Renzulli \& Reis, 1985). Psychologist Ellen Winner (1996) defines gifted children as: 1) precocious, 2) intrinsically-driven and creative, 3) having an intense and obsessive interest with an ability to focus sharply, and experience state of flow - optimal states in which they focus carefully and lose sense of the outside world. Science is defined as neutral observation and regular accumulation of information obtained from experiments (Topsakal, 1999); network of theories logically connected to each other (Medawar, 2003); a process of obtaining and organizing information by scientific methods (Çepni, 2007). The domains of scientific literacy in this study include: (1) science content; (2) the interaction between science, technology, and society; (3) the nature of science; and (4) attitudes toward science (Chin, 2005). For this reason, scientific attitude is important for developing scientific literacy. This study aims to determine scientific attitude levels of gifted students in Malatya Science and Arts Center, and to investigate whether their levels of scientific attitude differ on selected demographic variables. For this reason, research questions addressed in this study were as follows: (1) How often gifted students display scientific attitudes? (2) Does their display of scientific attitudes differ on gender, age, and school type, level of parental education, mother's occupational status, and monthly income?

\footnotetext{
${ }^{*}$ Res. Assist., Inonu University, Malatya, Turkey, ismail.san@inonu.edu.tr

*** Ph.D, Science and Arts Center, Malatya, Turkey, aihsan422@gmail.com
} 
Methods: The sample of this survey study consisted of 147 gifted students studying in Science and Arts Center (SAC) in Malatya, Turkey. No sampling procedures were employed in this study. Data were collected through the "Scientific Attitude Scale" developed by Battal and Gürgan (1998). The Cronbach alpha reliability coefficient was computed as 0.708 which is almost high (George \& Mallery, 2003). Frequency and percentage tables, $\mathrm{t}$ tests, analyses of variance and chi-square tests were employed to analyze the data. Data were analyzed by independent-samples $t$ tests and one-way analyses of variance when groups were normally distributed. Mann-Whitney $U$ tests and Kruskall-Wallis $H$ tests were employed when groups deviated from normal distribution (Büyüköztürk, 2002, p. 153), and Mann-Whitney $U$ tests to determine differences between groups. The "Scientific Attitude Scale" is composed of 22 items and scores obtained from this scale ranges from 22 to 88 . Scores closer to 88 show a higher level of scientific attitude. The mean score obtained from the scale is 69.25 and the standard deviation is 6.28 .

Results: According to the results of this study, 147 gifted students aged between 12 and 16 studying in the SAC in Malatya, Turkey:

1. have higher levels of scientific attitudes ( $X=69.28)$.

a) were found to always do the following: "Giving effort to learn things unknown”, "being honest to self and environment”, "looking for logic behind others' ideas", "providing references to scientific knowledge in his research, if necessary", "distinguishing between the real and the unreal", "asking for evidence against claims put forward", "looking for the reality, thinking what he knows do not reflect the real", "fighting patiently against difficulties", "being sensitive to distinction between phenomenological facts and personal ideas", "investigating causes in addition to effects", "purchasing and reading scientific publications", "investigating meaning of the data collected from all sources available".

b) were found to usually do the following: "Considering possible consequences of any attempt at the outset", "thinking systematically to solve problems encountered", "avoiding from any kind of deception through investigating the truth", "criticizing events", "thinking of a possible error in his ideas", "being calm to apply decisions until adequate amount of knowledge received”, “questioning decisions thought to be correct”, "changing his own ideas when new evidence presented".

c) were found to sometimes do the following: "Making plans" and "Avoiding personal ideas when faced with objective findings”.

1. Gifted students' levels of scientific attitudes do not differ on gender, age, school type, monthly income, maternal education level, and occupational status of parents.

2. According to the results of chi-square;

a) Girls' observed level of the following characteristics were higher than expected: "Looking for logic behind others’ ideas", "looking for the reality, thinking 
what he knows do not reflect the real", "thinking of a possible error in his ideas", and "making plans"

b) Students aged between 13 and 16 had a higher observed level of "critical thinking" than expected. Also, those aged between 12 and 13 had a higher observed level of "Searching all resources for research" level than expected.

c) Students in science schools had a higher observed level of "critical thinking" while students in elementary schools had a higher level of "distinguishing between the real and the unreal”.

d) Students having monthly income of 4001-5000 TL had a higher observed level of "critical thinking".

e) Students whose fathers had a high school or a college degree had a higher observed level of "changing his own ideas when new evidence presented" than expected.

f) Students whose mothers had graduate and elementary school degree had a higher observed level of "being sensitive to distinction between phenomenological facts and personal ideas", students whose mothers had elementary school degree had a higher observed level of "awareness of all references in a research paper", students whose mothers had graduate degree had a higher observed level of "being sensitive to distinction between phenomenological facts and personal ideas” than expected.

g) Students whose mothers are working had a higher observed level of "being skeptical about ideas” than expected.

Discussion and Conclusions: Based on these findings, the recommendations are as follows:

1) This research reveals scientific attitude levels of gifted students according to their own perceptions. Scientific attitude levels lof gifted students might be tested by different methods (e.g., qualitative) and then compared with the results of this research.

2) To higher gifted students' scientific attitude levels, teachers of SACs and their parents should be in a closer contact.

3) Teachers of SACs should be a model of "avoiding personal ideas when faced with objective findings"..

4) Contributions of gifted people who display scientific attitudes to our country will be the greatest. For this purpose, similar studies should be done by various methods in all SACs in Turkey. Then, obtained results should be evaluated by the Ministry of National Education.

5) Science, mathematics and social studies teachers of SACs should plan activities that develop scientific attitudes of gifted students. 


\section{Üstün Yetenekli Öğrencilerin Bilimsel Tutum Düzeyleri (Malatya Örneği)}

\author{
İsmail SAN*
}

\author{
Ali İhsan BORAN**
}

Makale Gönderme Tarihi: 05 Temmuz 2012

Makale Kabul Tarihi: 01 May1s 2013

ÖZET: $\mathrm{Bu}$ araştırmanın amacı, üstün yetenekli öğrencilerin bilimsel tutum düzeylerini belirlemek, öğrencilerin bilimsel tutum düzeylerinin demografik değişkenlere göre farklılaşıp farklılaşmadığını araştırmaktır. Araştırmada ilişkisel tarama modeli kullanılmıştır. Çalışma evrenini Malatya Bilim ve Sanat Merkezine (BİLSEM) kayıtlı 12-16 yaşlarında 147 üstün yetenekli öğrenci oluşturmaktadır. Bu öğrencilerin tamamına ölçek uygulanmıştır. Araştırmada veriler, Battal ve Gürgan (1998) tarafından hazırlanan Likert tipi “Bilimsel Tutum Ölçeği” kullanılmıştır. Ölçeğin güvenirliği için yapılan Cronbach alpha güvenirlik analizinde güvenirlik, 0.708 olarak tespit edilmiştir. Toplanan verilerin çözümlenmesinde yüzde, frekans tabloları, $t$ testi, ANOVA ve Ki-kare'den yararlanılmıştır. Elde edilen bulgular, üstün yetenekli öğrencilerin bilimsel tutum düzeylerine yaş, okul türü, cinsiyet, ailenin ortalama aylık geliri, anne-baba eğitim durumu ve anne meslek durumunun anlamlı bir etkisinin olmadığını göstermiştir. Maddeler, üzerinde yapılan Ki-kare testi sonuçlarına göre değerlendirilmiştir. Üstün yetenekli bireylerin bilimsel tutum düzeylerini yükseltmek için üstün yetenekli öğrencilere ve BİLSEM öğretmenlerine önerilerde bulunulmuştur.

Anahtar Sözcükler: üstün yetenekli öğrenci, bilimsel tutum, Bilim ve Sanat Merkezi (BİLSEM)

\section{Giriş}

Üstün yeteneklilik, ortalamanın üzerinde bir kabiliyet, yaratıcı düşünme ve görev sorumluluğunun bir bileşimi olarak tanımlanmaktadır (Renzulli \& Reis, 1985). Diğer çocuklara göre daha hızlı ve kendilerine has yollarla öğrendikleri gibi öğrenme konusunda kendilerine daha çok güvenen üstün yetenekli çocuklar, öğrenme ve algılamada yardıma ihtiyaç duymayıp kendi kendilerine motive olurlar ve bu çocukların sık sık yeni şeyler icat etme gayreti içinde oldukları görülür (Winner, 1996). Bu gayretleri onların belli başlı konularda derinlemesine çalışmalarını sağladığı gibi bu çocuklar, normalden daha uzun bir konsantrasyona ve odaklanma gücüne sahip olmaları ile (Neumeister, Adams, Pierce, Cassady, \& Dixon, 2007) diğer birçok çocuktan ayrılmaktadırlar. $\mathrm{Bu}$ farklılıkların iyi değerlendirilmesi ise ülke kalkınması adına oldukça önemlidir. Zira üstün yetenekli bireylerin toplumların yükselmesinde ve gelişmesindeki, sanat, eğitim, bilim ve teknoloji gibi alanlardaki katkısı göz ardı edilemez bir gerçektir (Ciğerci, 2006). Bu da ancak onların daha iyi anlaşılması ile mümkün olacaktır.

Üstün yetenekli öğrencilerin performanslarını ve potansiyellerini maksimum seviyeye çıkarabilmek için öncelikle onların anlaşılması gerekmektedir. Herhangi bir eğitim girişiminin ihtiyaçlar belirlenmeden başlatılması çok kereler başarısızlığı beraberinde getirmiştir (Demirel, 2003; Ertürk, 1974). Bu nedenle öğrenci grubunun özelliklerinin belirlenmesi gerekmektedir. "Bir eğitim kurumunun, çocuklar, gençler ve yetişkinler için sağladığı, milli eğitim ve kurumun amaçlarının gerçekleştirilmesine dönük tüm faaliyetleri kapsayan (Varış, 1996) eğitim programının birbiri ile dinamik ilişkiler içinde olan ögelerinin (Demirel, 2003) belirlenmesi aşamasında ortalama

\footnotetext{
* Araş. Gör., İnönü Üniversitesi, ismail.san@inonu.edu.tr

*** Dr., Bilim ve Sanat Merkezi, Malatya, aihsan422@gmail.com
} 
düzeydeki öğrencilere uygulananın dışına çıkılması gerekmektedir (Abram, 1982). Bu bireyler normal programlar yolu ile sağlanamayan geniş kapsamlı eğitime ve olanaklara ihtiyaç duyarlar (Renzulli \& Reis, 1985). Bu gerekçelerle ülkemizde üstün yetenekli öğrencilerin eğitimi için kurulan Bilim ve Sanat Merkezleri ilk olarak 1993 y1lında Ankara, İstanbul, İzmir, Denizli ve Bayburt illerinde kurulmuştur (Gökdere \& Küçük, 2003). Türkiye'de 2012 yılı itibari ile Milli Eğitim Bakanlığı bünyesinde öğrenci kabul eden Bilim ve Sanat Merkezi sayısı 60’1 geçmiştir.

Gözlemlerde tarafsılık ve deneylerden elde edilen bilgilerin düzenli birikimi (Topsakal, 1999); doğal dünyanın neye benzediği hakkındaki en son düşüncelerimizi temsil eden, birbirlerine mantıkla bağlanmış teoriler ağı (Medawar, 2003); bilimsel metotlar kullanarak sistematik bilgi edinme ve bilgiyi düzenleme süreci; evreni anlama ve tanımlama gayretleri (Çepni, 2007) olarak tanımlanabilen bilim, insanoğlunun doğayı ve evreni anlama ve ortaya çıkan olayları yordayıp kontrol etme çabaları olarak düşünülebilir.

Bilimsel tutum, bireyin karşılaştığı sorunları, olayları ve durumları kendi düşüncelerinden elinden geldiği ölçüde ayırıp eldeki mantıksal verilere dayanarak yorumlayabilmesi olarak tanımlanmaktadır. Bilimsel tutuma sahip insanlar birçok özellik bakımından diğer insanlardan ayrılırlar. Bu insanlar, araştırıcı ve eleştirici özelliğe sahip olup önyargıların ve dogmatik inanç sisteminin etkisinde kalmazlar. Bu bireyler, çevredeki olumsuz durumları tanıma ve çözme isteğinde olup bunun için çözüm yolları arama çabası içine girerler. Seçeceği çözümü inançla uygularken çözümü eleştirecek olanların görüşlerine değer verirler. Bilimsel tutumlar, bireyin başarılı olmasını sağlamasının yanı sıra düşüncesini de etkileyerek gelişimini sürekli kılar (Başaran, 1978, aktaran Demirbaş \& Yağbasan, 2005). Gelişimin sürekliliği, bir yandan değişimi zorunlu k1larken diğer yandan da geçmişten ders alabilme kabiliyetini gerektirmesine rağmen toplumda çok sık görülememektedir. Az sayıda insanın bilimsel tutum sahibi olması da onların teşhis edilmesinin ve yeteneklerinin geliştirilip doğru şekilde değerlendirilmesinin önemini artırmaktadır.

Bilimsel tutumun gelişmesinde diğer gelişim alanlarında olduğu gibi bireysel ve çevresel faktörlerin etkili olduğu (Senemoğlu, 2005) söylenebilir. Çevresel faktörler, insanda var olan potansiyelin kullanımı açısından oldukça önemlidir. İnsanın bulunduğu çevrede merakını gidermesine yardım eden kişi, kurum ve imkânların bulunmasının bilim yapma konusunda teşvik edici rol oynayacağı söylenebilir. Bilimsel bilginin üst düzey düşünme becerileri ile birleştirilmesine yardım edecek olan kişi, kurum ve imkânlar, insanın, çevresinde olup bitene bilim penceresinden bakmasına yardımcı olacaktır. Bilimsel okur-yazarlık olarak da adlandırılabilecek bu beceri ile bilimin varlığını sürdürmesi ve ilerlemesi daha da kolaylaşacaktır. Bilimsel okuryazarlık; a) bilimin içeriği, b) teknoloji, bilim ve toplum arasındaki ilişki, c) bilimin doğası, d) bilime karşı tutum (Chin, 2005) gibi parametreleri olan çok boyutlu bir beceridir. Bu nedenle, bilimsel okuryazarlığın yerleşmesi için bilimsel tutumun önemli olduğu söylenebilir. 
Bilime karşı olumlu tutum besleyen öğrenciler bununla beraber öğretmenlerine, eğitim programlarına, derslerine, okullarına karşı da olumlu tutum geliştirirler. Öğrencilerin bilime karşı olumlu tutum geliştirmelerinde öğretmenler ile anne ve babaların etkisi büyüktür. Öğrencilerin okula karşı tutumları ile onların anne ve babalarının eğitime karşı ilgi düzeyleri arasında pozitif bir ilişki vardır (Keeves, 1975). Anne ve babaların çocuklarını bilimsel faaliyetlere yönlendirmeleri çocukların bilime karş1 olumlu tutum geliştirmelerini sağlamaktadır. Öğrencilerin bilime karşı tutumlarında sınıf arkadaşlarının bilime karşı tutumlarının, öğretmenlerin ve annebabaların tutumlarından daha etkili olduğunu gösteren araştırmalar da yapılmıştır (Gogolin \& Swartz, 1972; Haladyna, Olsen, \& Shaugnessy, 1982; Walberg, Fraser, \& Welch, 1986).

Öğrencilerin bilime bakış açıları konusunda yapılan araştırmalar, genelde fen bilimlerine karşı tutumlar üzerinde yoğunlaşmaktadır. Yapılan araştırmaların birçoğu tutumla başarı arasında pozitif bir ilişki olduğunu göstermektedir (George, 2003; Papanastasiou, 2002; Papanastasiou \& Zembylas, 2002). Fen bilimleri alanına yönelik tutumların yanı sıra bilimsel tutumların araştırıldığı da görülmektedir (Byrne \& Johnstone, 1988; Koballa, 1988). Schibeci (1983) yaptığı çalışmasında fen bilimlerine yönelik tutumlar ile bilimsel tutumları ilişkilendirmiş ve bilimsel tutumları kazanan öğrencilerin fen bilimlerine yönelik tutumlarınında gelişeceğini açıklamıştır.

Üstün yetenekli öğrencilerin tutumlarına yönelik alanyazın incelendiğinde az sayıda araştırma olduğu görülmektedir (McGinnis \& Stefanich, 2007). Yapılan araştırmalardaki ortak kanı ise bilimsel terminolojinin soyut ve karmaşık yapısını anlayabilmede, üstün yetenekli öğrencilerin diğerlerinden daha başarılı olduğu yönündedir. Üstün yetenekliler için fen öğretiminin akranlarına göre daha anlamlı ve daha ilginç olduğu (Joyce \& Farenga, 1999; van Tassel-Baska \& Stambaugh, 2006) şeklinde de ifade edilebilecek olan bu durum, üstün yeteneklilerin eğitimini şekillendirmede belirleyici unsur olmaktadır.

Cürebal (2004), 13-18 yaşlarındaki üstün yetenekli öğrencilerin fen ve öğrenme ortamına karşı tutumlarını incelediği çalışmasında öğrencilerin sınıf düzeyleri (yaşları) düştükçe fen dersine karşı tutumlarının geliştiğini belirtmiştir. Tereci, Aydın ve Orbay (2008) üstün yetenekli öğrencilerin fen tutumlarını inceledikleri çalışmada, cinsiyete göre fen tutumlarının değişmediği sonucuna ulaşılmıştır.

Bilen ve Özel (2012) üstün yetenekli öğrencilerin biyoteknolojiye yönelik bilgilerini ve tutumlarını inceledikleri çalışmada üstün yetenekli öğrencilerin canlıya ve çevreye karşı duyarlı oldukları sonucuna ulaşmışlardır.

Ergin ve Özgürol (2011) bilimsel tutum ve duygusal zekâ arasındaki ilişkiyi incelemişler, duygusal zekâsı yüksek öğrencilerin bilimsel tutum düzeylerinin de yüksek olduğu sonucunu elde etmişlerdir.

Yapılan çalışmalarda elde edilen sonuçlar doğrultusunda üstün yetenekli öğrencilerin bilimsel tutumlarının bazı değişkenlere göre farklılaşabildiği ancak genel anlamda yüksek düzeyde olduğu ve bilimsel tutum ile fen tutumu kavramlarının binişik kullanıldığı görülmektedir. Öğrencilerin fene yönelik tutumları ile bilimsel tutumları 
birbirine çok yakın olmakla beraber, bilimsel tutum kavramı daha geniş kapsamlıdır. Bu araştırmada üstün yetenekli öğrencilerde bilimsel tutum düzeyleri incelenmiştir. Malatya'da Bilim ve Sanat Merkezine devam eden 12-16 yaşlarındaki üstün yetenekli öğrencilerin bilimsel tutum düzeylerini saptamaya yönelik bu çalışmada aşağıdaki sorulara yanıt aranmıştır: (1) Malatya'daki üstün yetenekli öğrenciler, bilimsel tutum sergileyen insan özelliklerini hangi sıklıkla yansıtmaktadır? (2) Malatya'daki üstün yetenekli öğrencilerin bilimsel tutum düzeyleri; a) cinsiyet, b) yaş, c) okul türü, d) annebabanın eğitim durumu, e) annenin meslek durumu, f) ailenin ortalama aylık geliri değişkenlerine göre anlamlı farklılaşmakta mıdır?

\section{Yöntem}

\section{Araştırmanın Modeli}

$\mathrm{Bu}$ araştırma, üstün yetenekli öğrencilerin bilimsel tutum düzeylerinin belirlenmesini amaçladığı için betimsel yöntemin kullanıldığı nicel bir çalışma olup tarama modeline uygun olarak hazırlanmıştır. Çalışmada öğrencilerin demografik değişkenlerine göre bilimsel tutum puanlarının farklılaşıp farklılaşmadığı da incelendiği için nedensel karşılaştırma deseni kullanılmıştır.

\section{Evren ve Örneklem}

Araştırmanın evreni, 2011-2012 eğitim-öğretim yılında Malatya’da bulunan Bilim ve Sanat Merkezine devam eden 147 öğrenciden oluşmaktadır. Çalışma, evrenin tamamından toplanan verilerle gerçekleştirilmiştir. Dolayısıyla örnekleme yoluna gidilmemiştir. Araştırmaya katılan öğrencilere ilişkin kişisel bilgiler Tablo 1'de gösterilmiştir:

Tablo 1

Öğrencilerin Kişisel Bilgileri

\begin{tabular}{lcc}
\hline Yaş & $N$ & $\%$ \\
\hline 12 & 35 & 23,8 \\
13 & 37 & 25,2 \\
14 & 14 & 9,5 \\
15 & 18 & 12,2 \\
16 & 43 & 29,3 \\
\hline Cinsiyet & $N$ & $\%$ \\
\hline Bay & 73 & 49,7 \\
Bayan & 74 & 50,3 \\
\hline Annenin mesleki durumu & $N$ & $\%$ \\
\hline Ev hanımı & 65 & 44,2 \\
Çalışan & 82 & 55,8 \\
\hline Anne Eğitim Durumu & $N$ & $\%$ \\
\hline İlköğretim mezunu & 29 & 19,7 \\
Lise ve dengi okul mezunu & 35 & 23,8 \\
Önlisans mezunu & 13 & 8,8 \\
Lisans mezunu & 63 & 42,9 \\
Lisansüstü mezunu & 7 & 4,8 \\
\hline
\end{tabular}

\begin{tabular}{lcc}
\hline Okul Türü & $N$ & $\%$ \\
\hline Özel İlköğretim Okulu (ÖİO) & 30 & 20,4 \\
Devlet İlköğretim Okulu (DİO) & 45 & 30,6 \\
Fen Lisesi (FL) & 39 & 26,5 \\
Anadolu Lisesi (AL) & 33 & 22,4 \\
\hline Ailenin Ortalama Aylık Geliri & $N$ & $\%$ \\
\hline 1000 TL’den az & 6 & 4,1 \\
1001-2000 TL arası & 26 & 17,7 \\
2001-3000 TL aras1 & 48 & 32,7 \\
3001-4000 TL aras1 & 24 & 16,3 \\
4001-5000 TL arası & 20 & 13,6 \\
5001 TL ve üzeri & 23 & 15,6 \\
\hline Baba Eğitim Durumu & $N$ & $\%$ \\
\hline İlköğretim mezunu & 11 & 7,5 \\
Lise ve dengi okul mezunu & 26 & 17,7 \\
Önlisans mezunu & 17 & 11,6 \\
Lisans mezunu & 73 & 49,7 \\
Lisansüstü mezunu & 20 & 13,6
\end{tabular}


Tablo 1 incelendiğinde, öğrencilerin 12-16 yaşlarında oldukları ve cinsiyete göre dağılımlarının yarı yarıya olduğu görülmektedir. Devam ettikleri okul türlerinin oranlarının birbirlerine yakın olduğu, ailelerinin ortalama aylık gelirlerinin genellikle 1000-3000 TL arasında olduğu (\%66.7), annelerinin yarısından çoğunun çalıştığı (\%55.8), annelerin yarıya yakınının $(\% 42.9)$ ve babaların yarısının (\%49.7) lisans mezunu olduğu anlaşılmaktadır.

\section{Veri Toplama Aracı}

Araştırmada veri toplama aracı Battal ve Gürgan (1998) tarafından geliştirilen "Bilimsel Tutum Ölçeğì" kullanılmıştır. Bu ölçekte bilimsel tutum tek boyutlu bir yapıya sahiptir.

Toplam 22 maddeden oluşan Bilimsel Tutum Ölçeği, dörtlü Likert tipinde olup seçenekleri "her zaman”, "sık sık”, "ara sıra", "hiçbir zaman” şeklinde derecelenmiştir.

Ölçeğe verilen ortalama puanlarının hesaplanmasında;

\begin{tabular}{|c|c|}
\hline Hiçbir zaman & $1.00-1.75$ aras 1 \\
\hline Ara sira & $: \quad 1.76-2.50$ aras 1 \\
\hline Çoğu zaman & $: \quad 2.51-3.25$ aras1 \\
\hline Her zaman & $: \quad 3.26-4.00$ aras1 \\
\hline
\end{tabular}

olarak değerlendirilmiştir.

Öğrencilerle birebir görüşmeler yapılarak araştırmanın kapsamı tanıtılmış ve rızaları alındıktan sonra ölçek öğrencilere uygulanmıştır.

Dört kategorili olarak 147 kişilik öğrenci grubuna uygulanan ölçeğin Cronbach alpha güvenirlik katsayısı 0.708 olarak bulunmuştur. Bu değer, ölçeğin güvenirliğinin "kabul edilebilir" olduğunu göstermektedir (George \& Mallery, 2003).

Araştırmada kullanılan veri toplama aracı, bilimsel tutumla ilişkili özelliklerin gösterilme sıklıklarına ilişkin öğrencilerin kendilerine yönelik algılarını ölçmeye yönelik olup bu çalışmada elde edilen veriler, öğrencilerin bilimsel tutuma ilişkin özdeğerlendirmelerinden ibarettir.

\section{Verilerin Analizi}

Bu çalışmada, elde edilen veriler değerlendirilirken ölçeğin birinci bölümünde yer alan bağımsız değişkenler için betimsel istatistik hesaplamaları yapılmıştır.

Üstün yetenekli öğrencilerin bilimsel tutum düzeylerine ilişkin algılarının cinsiyet ve annenin meslek durumu değişkenlerine göre farklılık gösterip göstermediğini belirlemek amacıyla, öncelikle verilerin bağımsız değişkenlere göre normal dağılım gösterip göstermediğine Shapiro-Wilk testi uygulanarak bakılmıştır. Verilerin normal dağılım gösterdiği durumlarda, varyansların homojenliği de test edilerek $t$ testi; normal dağılım göstermediği durumlarda ise Mann-Whitney $U$ testi kullanılmıştır. Yaş, anne-baba eğitim durumları, ailenin ortalama aylık geliri ve okul türü değişkenlerine göre, varyansların homojenliği test edildikten sonra verilerin normal dağılım gösterdiği gruplar için tek yönlü varyans analizi, normal dağılım göstermediği 
gruplar için non-parametrik testlerden Kruskall-Wallis $H$ testi ve gruplar arası farklılığ belirlemek için de Mann-Whitney $U$ testi kullanılmıştır (Alpar, 2011).

"Bilimsel Tutum Ölçeği”nde toplam 22 madde yer almaktadır. Seçenekler, "her zaman”dan “hiçbir zaman”a (4'den 1'e) doğru sıralanmıştır. Dört boyutlu olan bu ölçekten alınabilecek en düşük ortalama puan 1 (en düşük toplam puan=22), en yüksek ortalama puan 4 (en yüksek toplam puan=88)'tür. Ortalama puanın 4'e yaklaşması öğrencilerin bilimsel tutum düzeylerinin yükselmesi, 1'e yaklaşması ise düşmesi

şeklinde yorumlanmıştır. Öğrencilerin cevap vermediği maddeler boş bırakılmış olup tüm veriler girildikten sonra ilgili maddede verilen yanıtların ortalaması atanmıştır. Yapılan testlerde anlamlılık düzeyi $(\mathrm{p}=.05)$ olarak alınmıştır. Veriler, analizler doğrultusunda tablolaştırılmış ve yorumlanmıştır.

\section{Bulgular}

$\mathrm{Bu}$ bölümde, araştırmanın problem cümlesi doğrultusunda oluşturulan iki alt probleme ilişkin bulgulara yer verilmiştir. Ölçeğin tümü için öğrencilerin elde ettikleri toplam puanların ortalaması 73.33 ve standart sapması 6.28 olarak hesaplanmıştır.

Üstün yetenekli öğrencilerin bilimsel tutum sergileyen insanın özelliklerini hangi sıklıkla gösterdiklerine ilişkin bulgular Tablo 2'de verilmiştir.

Ölçek maddelerine verilen yanıtların toplam puanları üzerinden alınan ortalama puanın genel ortalamasının $\bar{X}=3.33$ olduğu ve "her zaman" düzeyine karş1lık geldiği görülmektedir. Bu durumda üstün yetenekli öğrencilerin bilimsel tutum sergileyen insan özelliklerini yüksek düzeyde gösterdikleri yorumu yapılabilir.

Üstün yetenekli öğrencilerin bilimsel tutum sergileyen insan özelliklerinden bilmedikleri karşısında öğrenme çabası içine girme; kendine ve çevreye karşı dürüst ve samimi olma, en doğruyu kendinin bildiğini düşünmeyip başka görüşlerde mantık arama; gerektiğinde kaynak gösterebilme; gerçek ile söylentiyi birbirinden ayırabilme; ileri sürülen iddialar karşısında kanıt isteme; gerçeği bulmaya çalışma; güçlükler karşısında yılmadan sabırla mücadele etme; olgusal gerçekler ile kişisel görüş ayrımına duyarlılık; olayların nedenlerini araştırma; araştırmalarında yararlandığı kaynaklardan aldığ bilimsel bilgiler için gerektiğinde kaynak gösterebilme; bilimsel yayınları almak ve okumaktan zevk alma; araştırmalarında mümkün olabilecek her kaynağa ulaşıp amaca uygun veri toplayarak verilerin anlamını araştırabilme özelliklerini "her zaman" gösterdikleri anlaşılmaktadır. Buna karşın yaşadığı hayatı planlama ve objektif bulgular karşısında fikirlerini terk etme özelliklerini "ara sıra", diğer özellikleri ise "çoğu zaman" düzeyinde göstermektedirler. 


\section{Tablo 2}

\section{Öğrencilerin Bilimsel Tutum Sergileyen İnsan Özelliklerini Yansıtma Düzeyleri}

Özellikler

Bilmediklerim karşısında öğrenme çabası içerisine girerim.

Kendime ve çevreye karşı dürüst ve samimiyim.

*En doğruyu kendimin bildiğini düşündüğüm için karşı görüşlerde bir mantık aramam.

Araştırmalarımda, yararlandığım kaynaklardan aldığım bilimsel bilgiler için gerektiğinde kaynak $7551.05839 .5149 .5 \quad 0 \quad 0 \quad 3.42 \quad$ HZ(4) gösterebilirim.

Gerçek ile gerçek olmayan söylentiyi birbirinden ayırt edebilirim.

İleri sürülen iddialar karşısında kanıt isterim

*Bildiklerim gerçeği yansıttığı için gerçeğin arayışına gerek duymuyorum.

Güçlükler karşısında yılmadan, sabırla mücadele ederim.

Olgusal gerçekler ile kişisel görüş ayırımına duyarlı davranırım.

Olayları incelerken sonuçları üzerinde olduğu kadar, nedenleri üzerinde de durup sorunların kökenine inebiliyorum.

Bilim Teknik gibi bilimsel yayın ile bilimsel makaleleri almak ve okumak bana zevk verir.

Araştırmalarımda mümkün olabilecek her kaynağa ulaşıp amaca uygun veri toplayarak verilerin anlamını araştırabilirim.

Her girişimimin olası sonuçlarını başlangıçta düşünüp, dikkate alabilirim.

Karşılaştığım problemlerin çözümünde planlı ve sistematik düşünebilirim.

Yalnızca gerçeğin araştırıcılığını yaparak gerçek dışında her türlü kandırmadan kaçınırım.

Olayları eleştirici bir gözle değerlendiririm.

*Fikirlerimde bir yanılgı olabileceğini düşünmüyorum.

Kanıtlanmış yeterli bilgiye ulaşmadan kararlarımı uygulamada acele etmem.

*Doğru olduğunu düşündüğüm kararları sorgulamakla vakit kaybetmem.

*Yeni kanıtlara rağmen kendi görüşlerimin arkasında dururum.

* Hayatımı, plan yaparak sıkıcı hale getirmem.

Objektif bulgular karşısında kişisel görüşlerimi terk ederim.

Genel Durum (Bilimsel Tutum)

*: olumsuz yargılara verilen yanıtlar tersten kodlanarak değerlendirilmiştir.

HZ: Her zaman, ÇZ: Çoğu zaman, AS: Ara sıra, HiZ: Hiçbir zaman.

Maddeler üzerinden yapılan Ki-kare testi sonuçlarına göre öğrencilerin cinsiyetleri ile karşı1 görüşlerde mantık arama ( $\chi^{2}=10.092$, $\left.p=0.018\right)$, gerçeği bulmaya çalışma ( $\left.\chi^{2}=11.051, p=0.011\right)$, fikirlerinin yanlış olabileceğini düşünme $\left(\chi^{2}=9.151\right.$, $p=0.027)$ ve planlı bir hayat sürme $\left(\chi^{2}=10.732, p=0.030\right)$ özellikleri arasında

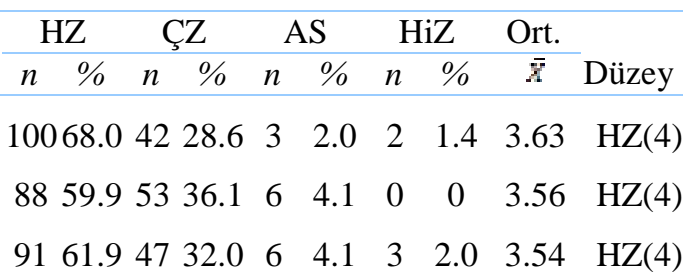

$7148.36544 .211 \quad 7.5 \quad 0 \quad 0 \quad 3.41 \quad \mathrm{HZ}(4)$

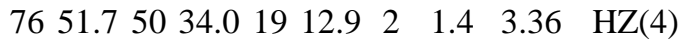

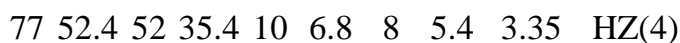

$6443.56644 .914 \quad 9.5 \quad 3 \quad 2.0 \quad 3.30 \quad \mathrm{HZ}(4)$

$6141.56950 .01610 .9110 .7 \quad 3.29 \quad \mathrm{HZ}(4)$

$6040.86947 .01812 .2 \quad 0 \quad 0 \quad 3.29 \quad \mathrm{HZ}(4)$

$7450.34429 .92416 .3 \quad 5 \quad 3.4 \quad 3.27 \quad \mathrm{HZ}(4)$

$6141.56644 .91912 .9 \quad 1 \quad 0.7 \quad 3.27 \quad \mathrm{HZ}(4)$

$5436.77349 .71912 .9 \quad 1 \quad 0.7 \quad 3.23 \quad$ ÇZ(3)

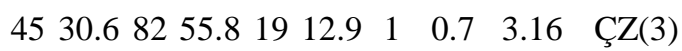

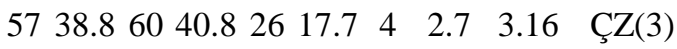

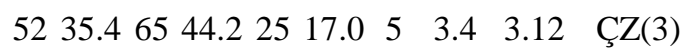

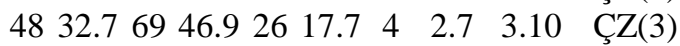

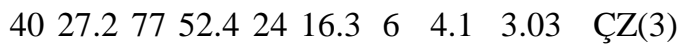

$2919.75034 .04832 .72013 .6 \quad 2.60 \quad$ ÇZ(3)

$1711.66443 .54732 .01912 .92 .54 \quad$ ÇZ(3)

$2013.64933 .34430 .03423 .12 .38 \quad \operatorname{AS}(2)$

$1510.23725 .26745 .62819 .02 .27 \quad \mathrm{AS}(2)$

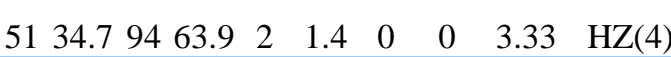


istatistiksel açıdan anlamlı bir ilişki olduğu görülmektedir. Örneklemdeki kız öğrencilerin karşıt görüşlerde mantık arama, gerçeği bulmaya çalışma, fikirlerinin yanlış olabileceğini düşünme ve planlı bir hayat sürme özellikleri için verdikleri yanıtlardan yüksek olanların oranı (observed), Ki-kare testinin hesapladığı beklenen değerden (expected) daha yüksek, düşük olanların oranı ise beklenenden daha düşüktür.

Öğrencilerin yaşları ile olayları eleştirici bir gözle değerlendirebilme $\left(\chi^{2}=23.575, p=0.023\right)$ ve araştırmalarında mümkün olan her kaynağa ulaşıp amaca uygun veri toplayarak verileri en iyi şekilde kullanabilme $\left(\chi^{2}=24.902, p=0.015\right)$ özellikleri arasında istatistiksel açıdan anlamlı bir ilişki olduğu görülmektedir. Örneklemdeki 13 ve 16 yaşlarındaki öğrencilerin olayları eleştirici bir gözle değerlendirebilme özelliği, 12 ve 13 yaşındaki öğrencilerin ise araştırmalarında mümkün olan her kaynağa ulaşıp amaca uygun veri toplayarak verileri en iyi şekilde kullanabilme özelliği için verdikleri yanıtlardan yüksek olanların oranı, (observed) Kikare testinin hesapladığı beklenen değerden (expected) daha yüksek, düşük olanların oranı ise beklenenden daha düşüktür.

Öğrencilerin devam ettikleri okul türü ile olayları eleştirici bir gözle değerlendirebilme $\left(\chi^{2}=23.597, p=0.005\right)$ ve gerçek ile gerçek olmayan söylentiyi birbirinden ayırabilme $\left(\chi^{2}=17.800, p=0.007\right)$ özellikleri arasında istatistiksel açıdan anlamlı bir ilişki olduğu görülmektedir. Örneklemdeki fen lisesine devam eden öğrencilerin olayları eleştirici bir gözle değerlendirebilme özelliğgi için, ilköğretim okuluna devam eden öğrencilerin ise gerçek ile gerçek olmayan söylentiyi birbirinden ayırabilme özelliği için verdikleri yanıtlardan yüksek olanların oranı (observed), Ki-kare testinin hesapladığı beklenen değerden (expected) daha yüksek, düşük olanların oranı ise beklenenden daha düşüktür.

Öğrencilerin ailelerinin ortalama aylık geliri ile olayları eleştirici bir gözle değerlendirebilme özelliği arasında istatistiksel açıdan anlamlı bir ilişki olduğu görülmektedir $\left(\chi^{2}=23.575, p=0.023\right)$. Örneklemdeki öğrencilerden ailesinin ortalama aylık geliri 4001-5000 TL arasında olanların olayları eleştirici bir gözle değerlendirebilme özelliği için verdikleri yanıtlardan yüksek olanların oranı (observed), Ki-kare testinin hesapladığı beklenen değerden (expected) daha yüksek, düşük olanların oranı ise beklenenden daha düşüktür.

Öğrencilerin babalarının eğitim durumu ile kanıtlar karşısında fikirlerini değiştirebilme $\left(\chi^{2}=21.451, p=0.044\right)$ özelliği arasında istatistiksel açıdan anlamlı bir ilişki olduğu görülmektedir. Örneklemdeki öğrencilerden babasının eğitim durumu lise ve lisans olan öğrencilerin kanıtlar karşısında fikirlerini değiştirebilme özelliği için verdikleri yanıtlardan yüksek olanların oranı (observed), Ki-kare testinin hesapladığı beklenen değerden (expected) daha yüksek, düşük olanların oranı ise beklenenden daha düşüktür.

Öğrencilerin annelerinin eğitim durumları ile olgusal gerçek ile kişisel görüş ayrımına duyarlı davranma $\left(\chi^{2}=32.294, p=0.009\right)$, araştırmalarında yararlandı $\breve{g}_{1}$ kaynaklardan aldığı bilgiler için gerektiğinde kaynak gösterebilme $\left(\chi^{2}=24.280\right.$, 
$p=0.019)$ ve gerçek ile gerçek olmayan söylentiyi birbirinden ayırabilme $\left(\chi^{2}=6.832\right.$, $p=0.032)$ özellikleri arasında istatistiksel açıdan anlamlı bir ilişki olduğu görülmektedir. Örneklemdeki öğrencilerden annesinin eğitim durumu ilköğretim ve lisans olan öğrencilerin olgusal gerçek ile kişisel görüş ayrımına duyarlı davranabilme özelliği için, ilköğretim olanlar araştırmalarında yararlandığı kaynaklardan aldığı bilgiler için gerektiğinde kaynak gösterebilme özelliği için ve lisans olanların gerçek ile gerçek olmayan söylentileri birbirinden ayırabilme özelliği için verdikleri yanıtlardan yüksek olanların oranı (observed), Ki-kare testinin hesapladığı beklenen değerden (expected) daha yüksek, düşük olanların oranı ise beklenenden daha düşüktür.

Öğrencilerin annelerinin mesleki durumları ile fikirlerinde yanılgı olabileceğini düşünme $\left(\chi^{2}=8.806, p=0.044\right)$ özelliği arasında istatistiksel açıdan anlamlı bir ilişki olduğu görülmektedir. Örneklemdeki öğrencilerden annesi çalışan öğrencilerin fikirlerinde yanılg1 olabileceğini düşünme özelliği için verdikleri yanıtlardan yüksek olanların oranı (observed), Ki-kare testinin hesapladığı beklenen değerden (expected) daha yüksek, düşük olanların oranı ise beklenenden daha düşüktür.

\section{Cinsiyet Değişkenine İlişkin Bulgular}

Öğrencilerin bilimsel tutum düzeylerinin kız ve erkek öğrenciler için normal dağılım gösterip-göstermediği incelendiğinde hem erkeklerin hem de kızların bilimsel tutum düzeylerinin normal dağılıma uygun olduğu görülmüştür. Bu durumda toplam puanlar üzerinden cinsiyet değişkenine göre parametrik olan $t$ testi uygulanabilir.

Tablo 3

Üstün Yetenekli Öğrencilerin Bilimsel Tutum Puanlarının Cinsiyet Değişkenine Göre t Testi Sonuçları

\begin{tabular}{cccccccc}
\hline Boyut & Değişkenler & $N$ & $\bar{X}$ & $S S$ & $S d$ & $t$ & $p$ \\
\hline \multirow{2}{*}{ Bilimsel Tutum } & Erkek & 73 & 70.14 & 6.095 & \multirow{2}{*}{145} & -1.733 & .085 \\
& Kiz & 74 & 68.36 & 6.375 & & & \\
\hline
\end{tabular}

Yapılan $t$ testi sonuçlarına göre; kızların bilimsel tutum sergileyen insan özelliklerini gösterme sıklıkları ile ( $\bar{X}=70.14$, SS=6.095) ile erkeklerinki ( $\bar{X}=68,36$, $S S=6.375)$ arasında anlamlı fark olmadığı $(t(145)=-1.733, p=.085)$ görülmüştür.

\section{Yaş Değişkenine İlişkin Bulgular}

Üstün yetenekli öğrencilerin bilimsel tutum sergileyen insan özelliklerini gösterme sıklıklarının yaş değişkenine göre anlamlı biçimde farklılaşıp farklılaşmadığını belirlemek amacıyla önce varyansların homojenliği test edilmiş ve varyansların homojen olduğunun belirlendiği toplam puan üzerine $F$ testi yapılmıştır. 
Tablo 4

Üstün Yetenekli Öğrencilerin Bilimsel Tutum Puanlarının Yaşlarına Göre F Testi Sonuçları

\begin{tabular}{cccccccccc}
\hline Yaş & $N$ & $\bar{x}$ & $S S$ & $\begin{array}{c}\text { Varyansın } \\
\text { Kaynağ }\end{array}$ & Kareler Top & Sd & Kareler Ort. & $F$ & $p$ \\
\hline 12 & 35 & 69.99 & 5.803 & Gruplararasi & 160.449 & 4 & 40.114 & 1.018 & .400 \\
13 & 37 & 70.55 & 6.870 & Gruplar İçi & 5594.223 & 142 & 39.396 & & \\
14 & 14 & 67.79 & 5.659 & Toplam & 5754.672 & 146 & & & \\
15 & 18 & 68.71 & 5.562 & & & & & \\
16 & 43 & 68.24 & 6.561 & & & & & \\
\hline
\end{tabular}

Tablo 4'e göre bilimsel tutum puanları öğrencilerin yaşlarına göre farklılık göstermemektedir $(F(4,142)=1.018, p=.400)$.

\section{Okul Türü Değişkenine İlişskin Bulgular}

Öğrencilerin bilimsel tutum düzeylerinin okul türü değişkenine göre normal dağılım gösterdiği belirlenmiş olup toplam puanlar üzerinden okul türü değişkenine göre tek yönlü varyans analizi uygulanmıştır.

Tablo 5

Üstün Yetenekli Öğrencilerin Bilimsel Tutum Düzeylerinin Okul Türlerine Göre F Testi Sonuçları

\begin{tabular}{|c|c|c|c|c|c|c|c|c|c|}
\hline $\begin{array}{l}\text { Okul } \\
\text { Türü }\end{array}$ & $N$ & $\bar{X}$ & SS & $\begin{array}{l}\text { Varyansın } \\
\text { Kaynağ1 }\end{array}$ & Kareler Top & $S d$ & Kareler Ort. & $F$ & $p$ \\
\hline 1.ÖİO & 30 & 71.08 & 5.823 & Gruplararas1 & 188.145 & 3 & 62.715 & 1.611 & .189 \\
\hline 2. DİO & 45 & 69.63 & 6.475 & Gruplar İçi & 5566.537 & 143 & 38.927 & & \\
\hline 3. FL & 39 & 67.92 & 5.898 & Toplam & 5754.672 & 146 & & & \\
\hline 4. AL & 33 & 68.65 & 6.653 & & & & & & \\
\hline
\end{tabular}

Tablo 5'te göre bilimsel tutum puanları öğrencilerin okul türüne göre farklılık göstermemektedir $(F(3,143)=1.611, p=.189)$.

\section{Ailenin Ortalama Aylık Gelir Değişkenine İlişkin Bulgular}

Öğrencilerin bilimsel tutum puanlarının ailenin ortalama aylık gelirine göre normal dağılım göstermediği görülmüştür. $\mathrm{Bu}$ nedenle toplam puanlar üzerinden ortalama aylık gelir değişkenine göre parametrik olmayan Kruskal-Wallis $H$ testi uygulanmıştır. 
Tablo 6

Üstün Yetenekli Öğrencilerin Bilimsel Tutum Düzeylerinin Ortalama Aylık Gelirlerine Göre Kruskal-Wallis Testi Sonuçları

\begin{tabular}{lccccc}
\hline Okul Türü & $N$ & Sira Ort. & sd & $X^{2}$ & $p$ \\
\hline 1000 TL'den az & 6 & 62.08 & 5 & 4.367 & .498 \\
1001-2000 aras1 & 26 & 73.21 & & & \\
2001-3000 aras1 & 48 & 66.11 & & \\
3001-4000 aras1 & 24 & 81.17 & & \\
4001-5000 aras1 & 20 & 76.50 & & \\
5001'den fazla & 23 & 84.40 & & \\
\hline
\end{tabular}

Öğrencilerin bilimsel tutum $(U=4.367, p=.498)$ puanları yaşlarına göre istatistiksel açıdan anlamlı düzeyde farklılık göstermemektedir.

\section{Baba Eğitim Durumu Değişkenine İlişkin Bulgular}

Öğrencilerin bilimsel tutum puanlarının baba eğitim durumuna göre normal dağılım gösterdiği belirlenmiş olup toplam puanlar üzerinden baba eğitim durumu değişkenine göre parametrik olan ANOVA testi uygulanmıştır.

Tablo 7

Üstün Yetenekli Öğrencilerin Bilimsel Tutum Puanlarının Baba Eğitimine Göre F Testi Sonuçları

\begin{tabular}{lcccllllll}
\hline \multicolumn{1}{c}{$\begin{array}{c}\text { Baba } \\
\begin{array}{c}\text { Eğitim } \\
\text { Durumu }\end{array}\end{array}$} & $N$ & $\overline{\boldsymbol{X}}$ & SS & $\begin{array}{c}\text { Varyansın } \\
\text { Kaynağı }\end{array}$ & Kareler Top & Sd & Kareler Ort. & $F$ & $p$ \\
\hline İlköğretim & 11 & 69.09 & 5.069 & Gruplararası & 44.183 & 4 & 11.046 & 0.275 & .894 \\
Lise & 26 & 69.49 & 6.153 & Gruplar İçi & 5710.489 & 142 & 40.215 & & \\
Ön-lisans & 17 & 69.12 & 6.936 & Toplam & 5754.672 & 146 & & & \\
Lisans & 73 & 68.88 & 6.492 & & & & & \\
Lisansüstü & 20 & 70.51 & 6.083 & & & & & \\
\hline
\end{tabular}

Öğrencilerin bilimsel tutum $[F(4,142)=0.275, p=.894]$ puanları baba eğitim durumuna göre istatistiksel açıdan anlamlı düzeyde farklılık göstermemektedir.

\section{Anne Eğitim Durumu Değişkenine İlişkin Bulgular}

Öğrencilerin bilimsel tutum puanlarının anne eğitim durumuna göre normal dağılım gösterdiği belirlenmiş olup toplam puanlar üzerinden anne eğitim durumu değişkenine göre parametrik olan ANOVA uygulanmıştır. 
Tablo 8

Üstün Yetenekli Öğrencilerin Bilimsel Tutum Puanlarının Anne Eğitimine Göre F Testi Sonuçları

\begin{tabular}{lccccccccc}
\hline $\begin{array}{c}\text { Anne } \\
\begin{array}{l}\text { Eğitim } \\
\text { Durumu }\end{array}\end{array}$ & $N$ & $\bar{X}$ & $S S$ & $\begin{array}{c}\text { Varyansın } \\
\text { Kaynağ }\end{array}$ & $\begin{array}{c}\text { Kareler } \\
\text { Top }\end{array}$ & Sd & $\begin{array}{c}\text { Kareler } \\
\text { Ort. }\end{array}$ & $F$ & $p$ \\
\hline Illköğretim & 29 & 70.73 & 6.283 & Gruplararası & 226.673 & 4 & 57.418 & 1.476 & 0.213 \\
Lise & 35 & 68.21 & 6.838 & Gruplar İçi & 5524.999 & 142 & 38.908 & & \\
Ön-lisans & 13 & 66.46 & 5.532 & Toplam & 5754.672 & 146 & & & \\
Lisans & 63 & 69.83 & 5.897 & & & & & & \\
Lisansüstü & 7 & 68.35 & 7.147 & & & & & & \\
\hline
\end{tabular}

Öğrencilerin bilimsel tutum $[F(4,142)=1.476, p=.213]$ puanları anne eğitim durumuna göre istatistiksel açıdan anlamlı düzeyde farklılık göstermemektedir.

\section{Anne Meslek Durumu Değişkenine İlişskin Bulgular}

Öğrencilerin bilimsel tutum düzeylerinin annesi çalışan veya ev hanımı olan öğrenciler için normal dağılım gösterdiği belirlenmiş olup toplam puanlar üzerinden anne mesleki durum değişkenine göre parametrik olan $t$ testi uygulanmıştır.

Tablo 9

Üstün Yetenekli Öğrencilerin Bilimsel Tutum Puanlarının Annenin Mesleki Durumuna Göre t Testi Sonuçlart

\begin{tabular}{cccccccc}
\hline Boyut & Değişkenler & $N$ & $\bar{X}$ & $S S$ & $S d$ & $t$ & $p$ \\
\hline \multirow{2}{*}{ Bilimsel Tutum } & Ev Hanımı & 65 & 69.45 & 6.500 & & & \\
& Çalışan & 82 & 69.09 & 6.133 & 145 & 0.346 & .730 \\
\hline
\end{tabular}

Anne mesleki duruma göre bilimsel tutum [annesi ev hanımı olan öğrenciler ( $\bar{X}=69.45$, SS=6.500), annesi çalışan öğrenciler $(\bar{X}=69.09, S S=6.133)(t(145)$ $=0.346, p=.730)]$, puanlarının ortalaması birbirine yakın olup aradaki küçük fark istatistiksel açıdan anlamlı değildir. Annesi çalışan öğrencilerin bilimsel tutum puanları ile annesi ev hanımı olan öğrencilerin puanları arasında fark yoktur.

\section{Sonuçlar ve Tartışma}

$\mathrm{Bu}$ araştırmadan elde edilen sonuca göre 2011-2012 eğitim-öğretim yılında Malatya Bilim ve Sanat Merkezine devam eden 12-16 yaş arasındaki 147 öğrencinin

1) Bilimsel tutumları yüksek düzeydedir. Bilişsel zekâ (IQ) puanları yüksek olanlar arasından seçilen bu ögrencilerin bilimsel tutum düzeylerinin yüksek olması bilimsel tutum ile zekâ arasında bir ilişki olabileceği şeklinde yorumlanabilir. Ergin ve Özgürol (2011)’in, IQ ile yakından ilişkili olan duygusal zekâ (EQ) ile bilimsel tutum arasındaki ilişkiyi inceledikleri çalışmada EQ düzeyi yüksek öğrencilerin bilimsel tutum 
düzeyinin de yüksek olduğu sonucuna ulaştıkları görülmektedir ki bu da araştırmada elde edilen bulgu ile paralellik göstermektedir.

Gerçek ile söylentiyi birbirinden ayırabilme (analiz), olgusal gerçekler ile kişisel görüş ayrımına duyarlı davranma (analiz), girişimlerin olası sonuçlarını başlangıçta düşünüp dikkate alabilme (değerlendirme), karşılaşılan problemleri eldeki mantıksal verilere dayanarak yorumlayabilme (sentez) gibi becerilerin arandığı bilimsel tutum, olayların ele alınış tarzı açısından düşünüldüğünde üst düzey zihinsel beceriler olan analiz, sentez ve değerlendirme düzeylerindeki davranışların bir arada kullanılmasını gerektirmektedir. Üst düzey zihinsel aktivitelerin yer aldığı bilimsel tutum sahibi insanların göstermesi beklenen davranışlar, yerine getirilmesi zor görevler olup üst düzeyden başlamak iyi bir yol değildir (Sönmez, 1999). Bu nedenle birçok insan, genellikle yanlış yönlendirme yüzünden üst düzey zihinsel davranışlara geçememekte ve bu davranışların gösterilme sıklığı genellikle düşük olmaktadır. Bu tür davranışları gösterebilen insanlarla diğerleri arasındaki farkın, zihinsel becerileri etkili kullanabilme düzeyi olarak yorumlanabilecek olan IQ puanı ile yordanabilmesi ise bilimsel tutumun doğası gereği duyuşsal yönleri ağır bassa da bilişsel yönünün de önemli etkiye sahip olduğunu göstermektedir.

Bilimin ön planda tutulduğu ortamlarda bilimi daha iyi yapıyor olmak değerli olduğundan tersine bir etki, bu ortamlarda diğer birçok toplumsal kurumdan daha az yaşanmakta ve üstün yetenekli öğrencilerin devam ettiği okullarda bilimsel tutum sergileme değer görmektedir. Bunun bir sonucu olarak, daha yüksek bilimsel tutum düzeyine sahip olanların nispeten düşük düzeyde bilimsel tutum sergileyenleri etkileyerek onların da düzeylerini zaman içinde yükselttikleri öne sürülebilir. Gogolin ve Swartz (1972), Haladyna ve diğerleri (1982); Walberg ve diğerleri (1986) yaptıkları çalışmalarda, üstün yetenekli öğrencilerin bilimsel tutum düzeylerinin yüksek olmasının, Bilim ve Sanat Merkezi ortamında öğrenim gören üstün yetenekli öğrencilerden bilime karşı çok yüksek düzeyde olumlu tutum geliştirenlerin, daha az düzeyde olumlu tutum geliştirenleri etkilemesinden kaynaklandı̆̆ı söylenebilir.

2) Bilimsel tutum sergileyen insanın özelliklerini gösterme sıklıklarına ilişkin algıları incelendiğinde;

a) Her zaman düzeyinde sırasıyla; "bilmedikleri karşısında öğrenme çabası içine girme", "kendine ve çevreye karşı dürüst ve samimi olma", "en doğruyu kendinin bilmediğini düşündügü için, başka görülerde mantık arama", "araştırmalarında, yararlandığı kaynaklardan aldığı bilimsel bilgiler için gerektiğinde kaynak gösterebilme", "gerçek ile gerçek olmayan söylentiyi birbirinden ayırabilme”, "ileri sürülen iddialar karşısında kanıt isteme", "bildiklerinin gerçeği yansıttığını düşünmeyerek gerçeğin arayışına girme", "güçlükler karşısında yılmadan sabırla mücadele etme", "olgusal gerçekler ile kişisel görüş ayrımına duyarlı davranma", "olayları incelerken sonuçlarının yanı sıra nedenlerini de araştırma", "bilimsel yayınları almak ve okumaktan zevk alma", "araştırmalarında mümkün olabilecek her kaynağa ulaşıp amaca uygun veri toplayarak verilerin anlamını araştırabilme" özelliklerini gösterdikleri görülmektedir. İkinci en yüksek düzeyde elde edilen "kendine ve çevreye 
karşı dürüst ve samimi olma”, Bilen ve Özel (2012)'nin çalışma bulgusuna paraleldir. Bireylerin kendilerine karşı samimi olması üstbilişsel bir beceriyi kullanabilmesine bağlı olup zeka ile üstbilişsel beceriyi kullanabilme arasında pozitif bir korelasyon olduğu (Karakelle, 2012) göz önünde bulundurulduğunda üstün yetenekli bireylerde kendine karşı samimi olma davranışının normal olduğu öne sürülebilir.

b) Çoğu zaman düzeyinde sırasıyla; "her girişimin olası sonuçlarını başlangıçta düşünüp, dikkate alabilme", "karşılaştığı problemlerin çözümünde, planlı ve sistematik düşünebilme”, "yalnızca gerçeğin araştırıcılığını yaparak, gerçek dışında her türlü kandırmadan kaçınma ", "olayları eleştirel bir gözle değerlendirme", "fikirlerinde bir yanılg1 olabileceğini düşünme", "kanıtlanmış yeterli bilgiye ulaşmadan kararları uygulamada acele etmeme", "doğru olduğunu düşündüğü karaları da sorgulamaya devam etme", "kendi görüşlerini yeni kanıtlar ortaya çıkınca değiştirebilme" özelliklerini gösterdikleri görülmektedir.

c) Ara sıra düzeyinde sırasıyla; "hayatı plan yaparak yaşama" ve "objektif bulgular karşısında, kişisel görüşlerini terk etme” özelliklerini gösterdikleri görülmektedir.

3) Üstün yetenekli öğrencilerin bilimsel tutum düzeylerinde, cinsiyet, yaş, okul türü, ailenin ortalama aylık geliri, anne-baba eğitim durumu ve anne meslek durumu bakımından anlamlı bir farka rastlanmamıștır. Bu da Cürebal (2004)'ün elde ettiği üstün yetenekli öğrencilerin yaşları ile fen dersine karşı tutumları arasındaki negatif ilişkinin bilimsel tutumla yaş arasında olmadığını, Tereci ve diğerlerinin (2008) elde ettikleri fen tutumlarının cinsiyete göre değişmediği gerçeğinin, bilimsel tutum ile cinsiyet arasında da geçerli olduğunu göstermektedir.

4) Maddeler üzerinden yapılan Ki-kare testi sonuçlarına göre

a) Kız öğrencilerin karşıt görüşlerde mantık arama, gerçeği bulmaya çalışma, fikirlerinin yanlış olabileceğini düşünme ve planlı bir hayat sürme özellikleri için verdikleri yanıtlardan yüksek olanların oranı beklenenden daha yüksek, düşük olanların oranı ise beklenenden daha düşüktür.

b) 13 ve 16 yaşlarındaki öğrencilerin olayları eleştirici bir gözle değerlendirebilme özelliği, 12 ve 13 yaşındaki öğrencilerin ise araştırmalarında mümkün olan her kaynağa ulaşıp amaca uygun veri toplayarak verileri en iyi şekilde kullanabilme özelliği için verdikleri yanıtlardan yüksek olanların oranı beklenenden daha yüksek, düşük olanların oranı ise beklenenden daha düşüktür.

c) Fen lisesine devam eden öğrencilerin olayları eleştirici bir gözle değerlendirebilme özelliğgi, ilköğretim okuluna devam eden öğrencilerin ise gerçek ile gerçek olmayan söylentiyi birbirinden ayırabilme özelliği için verdikleri yanıtlardan yüksek olanların oranı beklenenden daha yüksek, düşük olanların oranı ise beklenenden daha düşüktür.

d) Öğrencilerden ailesinin ortalama aylık geliri 4001-5000 TL arasında olanların olayları eleştirici bir gözle değerlendirebilme özelliği için verdikleri 
yanıtlardan yüksek olanların oranı beklenenden daha yüksek, düşük olanların oranı ise beklenenden daha düşüktür.

e) Öğrencilerden babasının eğitim durumu lise ve lisans olan öğrencilerin kanıtlar karşısında fikirlerini değiştirebilme özelliği için verdikleri yanıtlardan yüksek olanların oranı beklenenden daha yüksek, düşük olanların oranı ise beklenenden daha düşüktür.

f)Öğrencilerden annesinin eğitim durumu ilköğretim ve lisans olan öğrencilerin olgusal gerçek ile kişisel görüş ayrımına duyarlı davranabilme özelliği, ilköğretim olanların araştırmalarında yararlandığı kaynaklardan aldığı bilgiler için gerektiğinde kaynak gösterebilme özelliği ve lisans olanların gerçek ile gerçek olmayan söylentileri birbirinden ayırabilme özelliği için verdikleri yanıtlardan yüksek olanların oranı beklenenden daha yüksek, düşük olanların oranı ise beklenenden daha düşüktür.

g) Öğrencilerden annesi çalışan öğrencilerin fikirlerinde yanılgı olabileceğini düşünme özelliği için verdikleri yanıtlardan yüksek olanların oranı beklenenden daha yüksek, düşük olanların oranı ise beklenenden daha düşüktür.

\section{Öneriler}

1. Üstün yetenekli öğrencilerin bilimsel tutum düzeyleri farklı yöntemlerle (nitel araştırmalar, öğrencilerle görüşme, gözlem yöntemi vb.) tekrar test edilerek araştırma sonuçlarıyla karşılaştırılabilir.

2. Üstün yetenekli öğrencilerin matematik tutumları, fen bilimleri tutumları ve sosyal bilgiler tutumları da farklı yöntemlerle araştırılabilir. Elde edilen araştırma sonuçları birbirleri ve bunları kapsayan bilimsel tutum düzeyleri ile karşılaştırılabilir.

3. Üstün yetenekli öğrencilerin bilimsel tutum düzeylerinin yükseltilmesi için planlı bir hayat sürmelerine yardımcı olmak adına BİLSEM'lerdeki öğretmenlerle çocukların ailelerinin daha fazla iletişim içinde olmaları gerekmektedir. Ayrıca "objektif bulgular karşısında, kişisel görüşleri terk etme" konusunda BİLSEM öğretmenleri öğrencilere model olmaya çalışmalıdır.

4. Bilimsel tutum sergileyen üstün yetenekli bireylerin ülkemize olan katkıları, çok büyük olacaktır. Bu amaçla Türkiye'deki tüm BİLSEM'lerdeki üstün yetenekli öğrenciler için benzer çalışmalar değişik yöntemlerle yapılarak elde edilen sonuçlar Milli Eğitim Bakanlı̆̆ı tarafından değerlendirilmelidir.

5. BİLSEM'lerdeki özellikle fen bilgisi, matematik ve sosyal bilgiler öğretmenleri üstün yetenekli öğrencilerin bilimsel tutumlarını daha çok geliştiren etkinliklere yer vermelidir.

\section{Kaynakça}

Abram, G. C. (1982). Gifted education: The recruitment /selection process of teachers for gifted elementary programs and the perceptions of teachers and principals (Unpublished doctoral dissertation). University of Southern California, USA. 
Alpar, C. R. (2011). Uygulamalı çok değişkenli istatistiksel yöntemler. Ankara: Detay Yay.

Aydın, F., Çoşkun, M., Kaya, H., \& Erdönmez, İ. (2011). Gifted students' attitudes towards environment: A case study from Turkey. African Journal of Agricultural Research, 6(7), 1833-1876.

Başaran, İ. E. (1978). Eğitim psikolojisi. Ankara: Bilim Matbaası.

Battal, N., \& Gürgan, U. (1998, Eylül). Öğretmen adaylarının bilimsel tutum ve davranışları gösterme düzeyleri. III. Fen Bilgisi Eğitimi Sempozyumunda sunulmuş sözlü bildiri, Karadeniz Teknik Üniversitesi, Trabzon, Türkiye.

Bilen, K., \& Özel, M. (2012). Gifted students' knowledge of and attitudes toward biotechnology. Necatibey Eğitim Fakültesi Elektronik Fen ve Matematik Eğitim Dergisi, 6(2), 135-152.

Byrne, M. S., \& Johnstone, A. H. (1988). Critical thinking and science education. Studies in Higher Education, 25(8), 325.

Ciğerci, C. Z. (2006). Üstün yetenekli olan ve olmayan ergenlerde benlik saygısl, başkalarının algılaması ve psikolojik belirtiler arasındaki ilişkiler: Fen lisesi ve düz lise karşılaştırması (Yayımlanmamış yüksek lisans tezi). Sakarya Üniversitesi, Sakarya.

Chin, C. C. (2005). First-year pre-service teachers in Taiwan - Do they enter the teacher program with satisfactory scientific literacy and attitudes toward science? International Journal of Science Education, 27(13), 1549-1570.

Çepni, S. (2006). Kuramdan uygulamaya fen ve teknoloji öğretimi. Ankara: PegemA Yayıncilik.

Cürebal, F. (2004). Gifted students' attitudes towards science and classroom environment based on gender and grade level (Unpublished master's thesis). Middle East Technical University, Ankara.

Demirel, Ö. (2003). Kuramdan uygulamaya ĕgitimde program geliştirme. Ankara: PegemA Yayıncilık.

Demirbaş, M., \& Yağbasan, R. (2005). İlköğretim öğrencilerinin fen bilgisi dersindeki bilimsel tutumlarının belirlenmesi ve geliştirilmesine yönelik öneriler. 14.Ulusal Eğitim Bilimleri Kongresinde sunulmuş sözlü bildiri, Pamukkale Üniversitesi Eğitim Fakültesi, Denizli, Türkiye.

Duran, M. (2008). Fen öğretiminde bilimsel süreç becerilerine dayalı öğrenme yaklaşımının öğrencilerde bilime karşı tutumlarına etkisi (Yayımlanmamış yüksek lisans tezi). Muğla Üniversitesi, Muğla.

Ergin, D. Y., \& Özgürol, M. B. (2011, April). Bilimsel tutum ve duygusal zekâ arasındaki ilişki. Paper presented at the 2nd International Conference on New Trends in Education and Their Implications, Antalya, Turkey.

Ertürk, S. (1982). Eğitimde program geliştirme. Ankara: Meteksan Yay. 
George, R. (2003). Growth in students' attitudes about the utility of science over the middle and high school years: Evidence from the longitudinal study of American youth. Journal of Science Education and Technology, 12(4), 439-448.

Gogolin, L., \& Swartz, F. (1992). A quantitative and qualitative inquiry into the attitudes toward science of nonscience college students. Journal of Research in Science Teaching, 29(4), 487-504.

Gökdere, M. \& Küçük, M. (2003). Üstün yetenekli öğrencilerin fen eğitimdeki durumu: Türkiye örneklemi. Kuram ve Uygulamada Eğitim Bilimleri Dergisi, 3(1), 101-124.

Haladyna, T., Olsen, R., \& Shaugnessy, J. (1982). Relations of student, teacher and learning environment variables to attitudes toward science. Science Education, 66, 671-678.

Joyce, B. A., \& Farenge, S. J. (1999). Informal science experience, attitudes, future interest in science, and gender of high-ability students: An exploratory study. School Science and Mathematics, 99, 431-437.

Karakelle, S. (2012). Üstbilişsel farkındalık, zekâ, problem çözme algıı1 ve düşünme ihtiyacı arasındaki bağlantılar. Eğitim ve Bilim, 37(164), 237-250.

Keeves, J. P. (1975). The home, the school, and achievement in mathematics and science. Science Education, 59, 439-460.

Koballa, R. T. Jr. (1988). Attitude and related concepts in science education. Science Education, 72(2), 115-126.

Masters, B. R. (2009). A study of self-actualization of gifted children in public high school programs (Unpublished doctoral dissertation). Holos University, USA.

McGinnis, J. R., \& Stefanich, G. P. (2007). Special needs and talents in science learning. In K. Abell \& N. G. Lederman (Eds.), Handbook of research on science education (pp. 287-317). Mahwah, NJ: Lawrence Erlbaum Associates.

Medawar, B. P. (2003). Genç bilim adamına ögütler. Ankara: Tübitak Popüler Bilim Kitaplar1.

Neumeister, K. L. S., Adams, C. M., Pierce, R. L., Cassady, J. C., \& Dixon, F. A. (2007). Fourth-grade teachers' perceptions of giftedness: Implications for identifying and serving diverse gifted students. Journal for the Education of the Gifted, 30, 479-499.

Orbay, M., Gokdere, M., Tereci, H., \& Aydın, M. (2010). Attitudes of gifted students towards science depending on some variables: A Turkish sample. Scientific Research and Essays, 5(7), 693-699.

Papanastasiou, C. (2002). School, teaching and family influence on student attitudes toward science: Based on TIMSS data for Cyprus. Studies in Eucational Evaluation, 28, 71-86.

Renzulli, J. S., \& Reis, S. M. (1985). The schoolwide enrichhment model: A comprehensive plan for educational excellence. Mansfield Center, CT: Creative Learning Press. 
Senemoğlu, N. (2005). Gelişim, öğrenme ve ögretim kuramdan uygulamaya. Ankara: Gönül Yay.

Schibeci, R. A. (1983). Selecting appropriate attitudinal objectives for school science. Science Education, 67(5), 595-603.

Sowden, P., \& Christian, L. (1999). Parenting the young gifted child: Supportive behaviors. Roeper Review, 21(3), 215-221.

Sönmez, V. (1999). Öğretmen el kitabı. Ankara: Anı Yay.

Tereci, H., Aydın, M. \& Orbay, M. (2008, Mayıs). Bilim ve sanat merkezlerine devam eden ögrencilerin fen tutumlarının incelenmesi: Amasya BILLSEM Örneği. Üstün Zekâlı ve Yetenekli Çocuklar Kongresinde sunulmuş sözlü bildiri, Ankara.

Topsakal, S. (1999). Fen öğretimi. Bursa: Alfa Yayınları.

Uzun, S. (2011). İlköğretim 5. sınıf öğrencilerinin bilimsel bilgiye yönelik görüşlerinin ve fen bilimine yönelik tutumlarının incelenmesi (Yayımlanmamış yüksek lisans tezi). Rize Üniversitesi, Rize.

Uzun, M. (2004). Üstün yetenekli çocuklar el kitabı. İstanbul: Çocuk Vakfı Yayınları.

VanTassel-Baska, J., \& Stambaugh, T. (2006). Instructional manegement strategies for effective curriculum implementation. Comprehensive curriculum for gifted learners. Denver, Colorado: Pearson Education Inc.

Varış, F. (1996). Eğitimde program geliştirme "teori ve teknikler”. Ankara: Alkım Yay.

Walberg, H. J., Fraser, B. J., \& Welch, W. W. (1986). A test of a model of educational productivity among junior high school students. Journal of Education Research, 23, 699-706.

Winner, E. (1996). Gifted children: Myths and realities. New York: Basic Books. 